Riwayat draf artikel Diserahkan 15-022022

Direvisi 24-02-2022

Diterima 25-02-2022

Publish 27-02-2022

\section{Students' Perception in Learning English through Blended Learning}

Alma Sri Andriyani ${ }^{1}$, Maulina ${ }^{2 *}$, Syarif $\mathrm{Amin}^{3}$, Rahmat Nasrullah $^{4}$, Asdar ${ }^{5}$, Andi Hamsiah ${ }^{6}$

Department of English Language Education, Universitas Muhammadiyah Kendari, Indonesia ${ }^{1,3,4}$

Faculty of Teacher Training and Education, Universitas Bosawa, Indonesia ${ }^{5,6}$

Corresponding Email: maulina@umkendari.ac.id

\begin{abstract}
Mobile technology plays an equal role with face-to-face interaction in the learning process in this current era. One of the most prevalent utilized technologies is the use of social media of WhatsApp application in the online learning integrated with the face-to-face teaching and learning as called a blended-learning method. This recent study aims: (1) to investigate how the blended learning process is operated, and (2) to determine students' perceptions in learning English through blended learning. This study employed an explanatory mixed-method research design using observation, questionnaire, and interview to collect data from the purposively selected students. This study indicated that learning English through blended learning showed positive behavior like attending the class regularly and enthusiastically. Besides, students felt comfortable and enjoyed learning English, showing their English language skills and favorable learning in the form of well-implemented blended learning. Thus, researchers concluded that blended learning established essential behavioral, cognitive, and emotional aspects of students in English learning.
\end{abstract}

Keywords: blended learning, face-to-face interaction, learning English, perception, WhatsApp

ABSTRAK: Teknologi ponsel memiliki peran yang sama dengan interaksi tatap muka dalam proses pembelajaran di era ini. Salah satu teknologi yang paling sering digunakan adalah penggunaan media sosial yaitu aplikasi WhatsApp melaui pembelajaran dalam jaringan yang diintegrasikan dengan pengajaran dan pembelajaran tatap muka sebagaimana disebut sebagai metode pembelajaran campuran. Penelitian ini bertujuan: (1) untuk menyelidiki bagaimana proses pembelajaran campuran dilaksanakan, dan (2) untuk menentukan persepsi siswa dalam belajar Bahasa Inggris melalui pembelajaran campuran. Penelitian ini menerapkan metode penelitian campuran dengan menggunakan pengamatan, angket, dan wawancara untuk mengumpulkan data dari siswa yang dipilih dengan cermat. Studi ini menunjukkan bahwa belajar Bahasa Inggris melalui pembelajaran gabungan menunjukkan perilaku positif seperti hadir di kelas dan antusias. Selain itu, para siswa merasa nyaman dan menikmati proses belajar Bahasa Inggris dengan memperlihatkan keterampilan mereka dalam Bahasa Inggris melalui pembelajaran yang menguntungkan dalam bentuk pembelajaran terpadu yang diimplementasikan dengan baik. Oleh karena itu, para peneliti menyimpulkan bahwa proses pembelajaran campuran membentuk aspek perilaku, kognitif, dan emosi siswa yang penting dalam pembelajaran Bahasa Inggris.

Kata Kunci: pembelajaran campuran, interaksi tatap muka, belajar Bahasa Inggris, persepsi, WhatsApp 


\section{INTRODUCTION}

Technology has influenced students' learning styles and teaching methods in education using mobile learning. Mobile devices have also been shown to support approaches or learning styles in mobile learning. One of them is blended learning. Blended learning is also no longer a new term in Indonesia. Globally, it has proven to be popular in education and has been used for decades to this day. As seen historically, blended learning continues to change over time. One of the most commonly used in blended learning is that using social media. Social media provides a learning process anywhere and anytime in the world of education (Maulina et al. 2019; Maulina et al. 2020; Maulina et al. 2021; Saputra et al., 2021; Rasyiid et al., 2021) also, which takes precedence over the technical definition in blended learning, namely assumptions.

Blended learning is a learning approach that generally combines two learning styles, namely direct or face-to-face learning and online learning that uses all types of social media or modern technology considered a medium in learning. Sakina et al. (2020) blended learning is a new approach to teaching using various instruments that also use technological foundations in instruction. Besides, implementation of such approach in this disruptive era could lead educators and language learners aware the essence of learning in distance ways and face-to-face for a more complex understanding learning English Language. Since Putra et al. (2021) stated that the English language learning has some essential skills, such as listening, speaking, reading, writing, grammar, vocabulary, and other language aspects and components to be more communicatively studied.

Current technology has the potential for bridge space, but also for bridging time (through recording), and for individual learning (students can control the material, and the speed of learning). Besides, students have more flexibility in determining when, where, and how fast they will learn. Therefore, blended learning is a learning approach combining technological learning or in a trend known as face-to-face and online so that the learning process becomes more effective and efficient.

Azizan (2010) suggests that blended learning provides good benefits for instructors and students in teaching and learning activities, for instance, increasing social interaction, communication, and collaboration; offering flexibility and efficiency; expanding reach and mobility; and optimizing development costs and time.

Blended learning using the WhatsApp application combines face-toface or offline instructions and learning sessions using WhatsApp or online sessions. According to Qamar et al. (2019), the WhatsApp application is used as a medium to find out the unique interpretations of student groups used in discussions. WhatsApp is a mobile application run on all devices and operating systems currently used by all students also improve achievement, performance, and motivation in group formation (Sayan, 2016). Using social media, people can communicate about life issues such as education, politics, family, faith, etc. (Ahmad et al., 2020; Zainal et al., 2022). Smartphones are a tool for accessing social media. For example, the current trend is to access the 
WhatsApp application. Montag et al. (2015) said that WhatsApp had become a driving force that smartphones dominate our daily lives. learning through blended learning in this $21^{\text {st }}$ era will lead students to develop, acquire, comprehend, and produce English language extensively for both male and female students (Maulina, 2019; Maulina, 2015).

Student engagement is very important in measuring student perception. Perception is a process of one's actions on information owned through observation by the five senses. Perception is also information obtained from activities, the environment, and the process of understanding something and can help others who need the information they want to know. Mismara (2019), in his research, suggests that perception is the recognition of understanding through individual senses information about how one reacts to that information, and one uses that information with the aim that one can communicate with the environment around them.

Perception theory, according to Demuth (2013), perception is a process to obtain information that consists of two primary groups, namely the theory of direct perception (bottom-up) and the theory of indirect perception (topdown). Direct perception (bottom-up) is tangible information or facts by which sensory qualities determine or influence our final perception. Sensory input is people's views about something or experiences that happen to us and determines further processing. Meanwhile, indirect perception (top-down) is an opinion under the knowledge we have without having expertise.

According to Qiong (2017), the perception process consists of three stages: selection, organization, and interpretation. The first stage is selection. In the first stage in the perceptual process, we are transforming environmental stimuli into meaningful experiences. The second stage is organization. At this stage, we need to arrange them in several ways according to specific patterns of meaning. In this stage of perception, we will know the shape, color, texture, size, etc., in the event or social and physical object we encounter. Finally, the third stage in perception is interpretation. At this stage, it refers to the process of determining the meaning of the selected stimuli. After the stimuli chosen are categorized into structured patterns, we can try to understand these patterns by providing sense.

To determine and measure students' perceptions of blended learning, the researchers used three aspects of student engagement developed and defined according to (Trowler, 2010). These three aspects include: behavioral, emotional, and cognitive. The three aspects are first behavioral. It relates to student action. Pietarinen et al. (2014) said that behavioral engagement requires collaboration and active involvement of students in social groups, classroom interactions, and the process of teaching and learning activities both at school and at home and school-related extracurricular activities. Second, emotional relates to student reactions to learning. Kristine (2017) says that emotional involvement includes enthusiasm, satisfaction, and interest. Last is cognitive. Cognitive is related to the psychology of students in learning. Pietarinen et al. (2014) said that cognitive engagement refers to students' ability in learning activities, including self-regulation. This aspect is to measure students' engagement in blended learning. 
Therefore, in implementing blended learning, a teacher can use mobile devices in the learning process. Mobile devices are now available under any circumstances and can enhance the learning experience-one of the social media applications on smartphones, namely WhatsApp. WhatsApp, social media platform, can send text, images, videos, and sounds, suitable as a discussion tool (Qamar et al., 2019; Lar et al., 2021). It is in line with the finding study from Andretti (2016) that social media has changed how learning styles and environments from conventional learning models become visuals. This study investigates the blended learning process and determines students' perception of learning English through blended learning. This is in line with Maulina and Rusli (2019) that the current study aims at seeing the gap between theories and practices in the field of teaching English as a foreign language utilizing one of the most phenomenon ways of blended learning. Therefore, the findings from this analysis, the learning process through blended learning, and students' perceptions of learning English through blended learning are proposed to be developed and evaluated.

\section{METHODS}

This paper used an explanatory mixed-method research design to collect data. The purpose of this study was to focus on the process and results. According to Morse and Linda (2016), mixed methods research usually involves qualitative and quantitative methods. Qualitative analysis was carried out by observing for half a semester in the teaching and learning process. It was learning English through a blended learning approach that was face-to-face learning process run offline in the actual classroom that researchers can see how the teacher delivered lessons, materials used, interactions occurred while recorded and took field notes during the learning activities in the classroom to collect more accurate data. Meanwhile, in the online learning process using WhatsApp, researchers were also members of the group observing the teaching material delivery, discussion in texting, attaching material, sharing learning sources, asking and answering questions, and submitting the tasks. Both offline and online class versions enable researchers to monitor and observe an accessible learning process of blended learning.

Another measurement was the questionnaire distributed online to twenty-six junior high school students. The questionnaire consisted of fifteen close-ended statements was adapted from Towler (2010) regarding the assessment aspect when assessing the analysis results of this paper. The indicators displayed in the questionnaire included three significant aspects of behavioral, emotional, and cognitive aspects. First of all, behavioral aspects covered its sub-aspects of learning effectiveness and efficiency, learning participation, multi-tasking participation, learning collaboration, discussion involvement, and curiosity. The next one was emotional aspect included enthusiasm, comfort, and satisfaction. Finally, the cognitive aspect involved studious in learning, favorable, and skillful in blended learning. To get results from the questionnaire data, researchers used a Google form survey. The questionnaire analysis automatically displayed on the results from Google 
Form in the form of pie charts showing the participants' choices referring to the Likert scale of strongly agree, agree, neutral, disagree, and strongly disagree. That way, researchers found it was easier to find out students' perceptions of learning English using a blended learning approach.

In addition, to support the data of observation and questionnaire, researchers employed structured interviews asking several questions prepared previously to the interviewee or students. The interview content followed the blueprint of questionnaires asking the same indicators. Researchers prepared five questions to carry out the interview. First, the researchers selected purposively five students to be interviewed. The five students were chosen according to the criteria of the researchers that they who gave consent of giving relevant information in this study, they who had intensively experienced the blended learning atmosphere for a minimum of a year, and they who had more potential capabilities in elaborating answer of queries seen from the result of the questionnaire data result. Besides, the interview was by telephone and face-to-face. The time given during the interview was 25 minutes for every student. It means that one question was being answered in five minutes. After conducting the interview, the researchers drew conclusion.

\section{FINDINGS}

The analyzed data of the observation contained three aspects of the assessment during observation, including behavioral, emotional, and cognitive factors. Judging from the behavioral aspect, students show good behavior, are polite, always participate, continue to do assignments even though they are sometimes late when collected, and present when participating in the learning process. Furthermore, viewed from the emotional aspect, students as participants felt happy and always enthusiastic when participating in the offline (face to face) and online learning process (via the WhatsApp application) and did not feel bored while participating in the teaching and learning process, which was carried out once a week. Then assessed from the cognitive aspect, students showed their positive perception to motivate themselves when participating in the teaching and learning process using this blended learning model, both offline (face to face) and online (via the WhatsApp application).

\section{Student Demographic Background}

Table 1. Students Demographic Background

\begin{tabular}{|l|c|c|c|}
\hline Aspect & Category & Frequency & Percentage \\
\hline Gender & Male & 7 & $26.9 \%$ \\
& Female & 19 & $73.1 \%$ \\
\hline
\end{tabular}

Based on table 1 shows that $26.9 \%$ are male students and $73.1 \%$ are female students. Female students were the majority participants in this study. 
The following of the result of analysis English learning process through blended learning are presented.

\section{English Learning Process through Blended Learning}

\section{Learning Effectiveness and Efficiency}

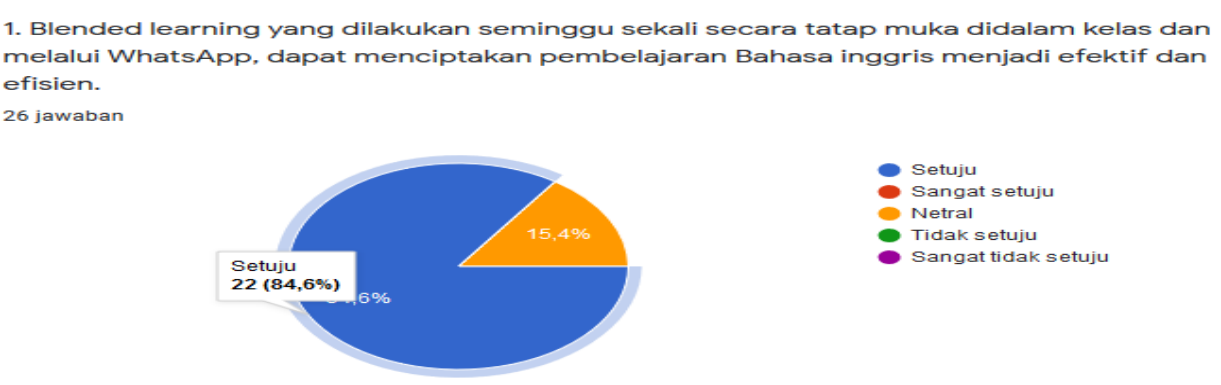

Figure 1. Learning Effectiveness and Efficiency

The following are answers from participants regarding Figure 1 learning effectiveness and efficiency, which shows that $84.6 \%$ said the scale "agrees," and $15.4 \%$ said "neutral." That way, the researcher concludes that the agree scale is an outline response from students. Students agree with blended learning, conducted once a week, and the teaching creates learning effectiveness and efficiency. The use of blended learning is increasingly popular in the world of education. Students are also interested and respond well to the blended learning style. In addition to offline learning (face to face), students also respond well to the online learning process via the WhatsApp application.

\section{Learning Participation}

2. Saya mengerti dan aktif saat mengikuti proses pembelajaran Bahasa inggris yang

dilakukan seminggu sekali baik belajar didalam kelas ataupun belajar melalui WhatsApp.

26 jawaban

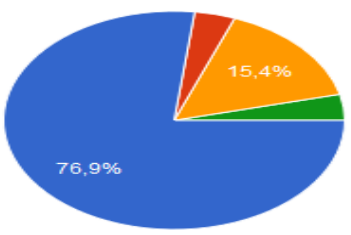

Setuju

Sangat setuju

Netral

Tidak setuju

Sangat tidak setuju

Figure 2. Learning Participation

Students are active in participating in the learning process, which is carried out once a week. The following is one of the items on the questionnaire that shows the responses of students with the results of the answers based on the Figure 2 that $76.9 \%$ of students chose to "agree," and $15.4 \%$ of students chose a "neutral" scale. Thus, the researchers conclude that judging from Figure 2, the "agree" scale remains the most preferred of 
students, which illustrates that students show good participation in learning English through blended learning.

\section{Multi-Tasking Participation in Learning}
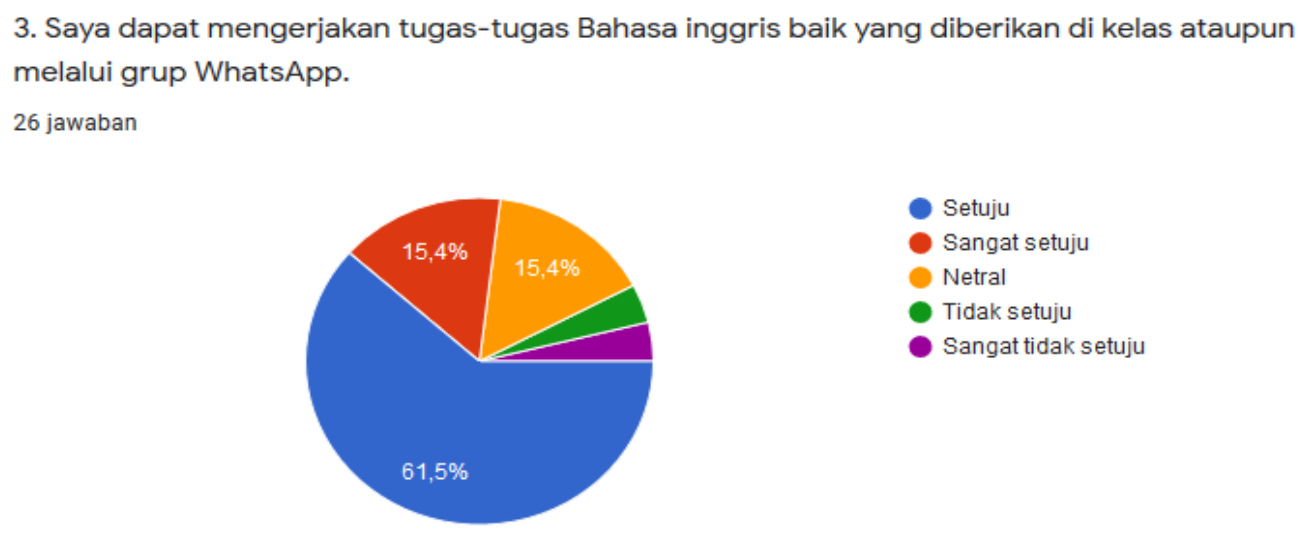

\section{Figure 3. Multi-Tasking Participation in Learning}

The Figure 3 is the result of the answer to one of the questionnaire items from the participants. Also, Figure 3 shows that $61.5 \%$ of students said they "agree", $15.4 \%$ of students said they "strongly agree", and $15.4 \%$ of students said "neutral". Thus, the researchers conclude that most students agree with the existence of multi-tasking in learning English through blended learning.

\section{Learning Collaboration}

4. Saya dapat bekerja sama dengan teman-teman jika ada tugas kelompok yang diberikan baik didalam kelas ataupun melalui WhatsApp.

26 jawaban
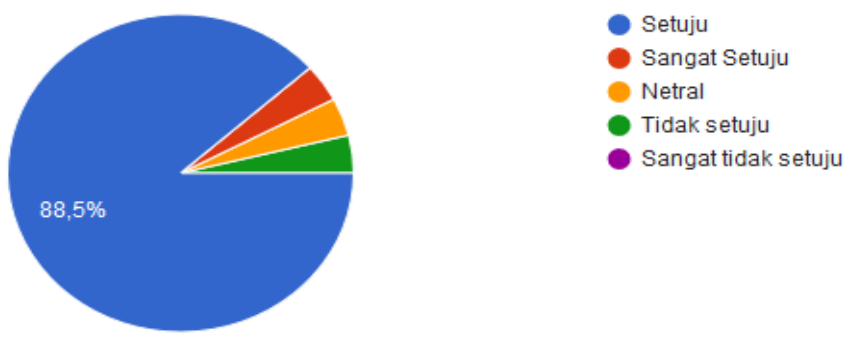

Figure 4. Learning Collaboration

The following is a response that shows the results of the answers from the Figure 4 which describes $88.5 \%$ of students said they "agree." Thus, the researchers conclude that most students agreed with the cooperation in doing group assignments with friends in learning English through blended learning. 


\section{Discussion Involvement}

5. Dengan belajar melalui grup WhatsApp, saya dapat berdiskusi dengan teman-teman tentang apa saja, baik dari materi, dan tugas, serta dapat dilakukan dimanapun dan kapanpun.

26 jawaban

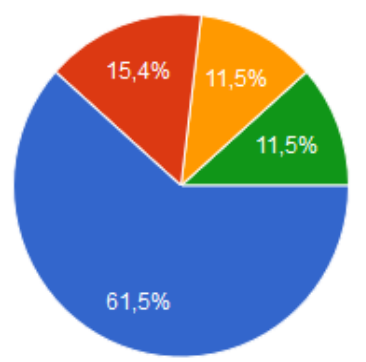

\section{Figure 5. Discussion Involvement}

Figure 5 describes the results of the answers to the questionnaire from the participants. $61.5 \%$ of students said they "agreed," $15.4 \%$ of students said "strongly agree," $11.5 \%$ of students said "neutral," and $11.5 \%$ of students said they "disagree." Thus, the researchers conclude that the agree scale was the most answered by the students. Students can be well involved in discussions when learning is done through WhatsApp groups. Although students chose strongly agree, neutral, and disagreed, the choice was very minimal, and the agree scale was the answer choice with the highest percentage.

\section{Curiosity in Blended Learning}

6. Dalam belajar secara tatap muka didalam kelas, saya dapat menanyakan ke guru dan juga teman-teman tentang materi atau tugas yang saya tidak mengerti yang sebelumnya telah dibagikan digrup WhatsApp.

26 jawaban

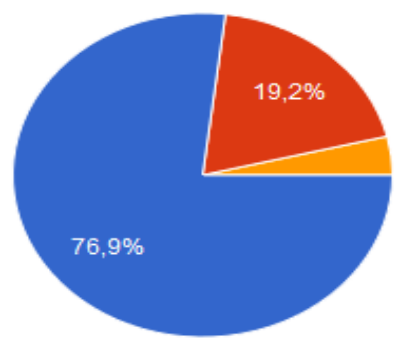

\section{Figure 6. Curiosity in Blended Learning}

Figure 6 illustrates that $76.9 \%$ of students said they "agreed," and $19.2 \%$ said they "strongly agreed." Thus, the researchers conclude that although

Copyright (c) 2022 Alma Sri Andriyani, Maulina Maulina, Syarif Amin, Rahmat Nasrullah, Asdar 
there are responses from students who strongly agree, the agreed points are the highest response percentage. The curiosity of students is immense in learning through blended learning. The six-item statement questions above are related to the process of learning English through blended learning. Of the six statements, the agree scale is the highest percentage. Blended learning in question is offline (face to face) and online (via the WhatsApp application). Therefore, students indirectly show interest in their feelings towards the learning process using this blended learning approach.

\section{Learning English through Face-to-face and through the WhatsApp Application}

\section{Behavioral Aspect}

In the behavioral aspect, students become more active in participating when participating in English learning activities through a blended learning approach that is carried out offline (face to face) and online (through WhatsApp applications/groups). The following are three behavioral aspects used to analyze students' perceptions of learning English through blended learning.

\footnotetext{
7. Saya selalu hadir dalam belajar Bahasa inggris yang menggunakan blended learning baik secara tatap muka didalam kelas ataupun melalui grup WhatsApp yang dilakukan seminggu sekali.

26 jawaban
}

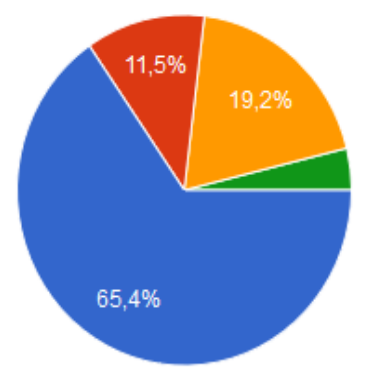

Setuju

Sangat setuju

Netral

Tidak setuju

Sangat tidak setuju

Figure 7. Presence in Learning

The items above are the results of the answers from Figure 7 shows that $65.4 \%$ of students "agree", $11.5 \%$ of students "strongly agree", and $19.2 \%$ of students who choose a "neutral" scale. Thus, the researchers conclude that the majority of students chose the agree scale. Students still pay attention to attendance in learning English through blended learning which is carried out once a week. 
8. Dengan menggunakan blended learning, Saya selalu mengumpulkan tugas dengan tepat waktu, baik kumpul didalam kelas maupun kumpul melalui grup WhatsApp.

26 jawaban

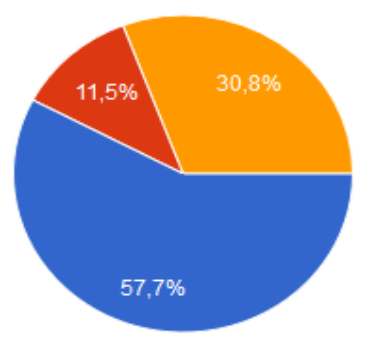

$$
\begin{aligned}
& \text { Setuju } \\
& \text { Sangat setuju } \\
& \text { Netral } \\
& \text { Tidak setuju } \\
& \text { Sangat tidak setuju }
\end{aligned}
$$

\section{Figure 8. Discipline in Blended Learning}

The following is the result of the answer from Figure 8 illustrates that $57.7 \%$ of students said they "agreed", $11.5 \%$ of students said "strongly agree", and $30.8 \%$ of students said "neutral". Thus, the researchers conclude that the percentage of agree is the majority of the students' response. Students show that they like blended learning and are disciplined in following the lessons.

\footnotetext{
9. Saya selalu mengikuti perintah guru untuk berpartisipasi dalam belajar Bahasa inggris baik didalam kelas maupun melalui grup WhatsApp yang dilakukan seminggu sekali

26 jawaban
}
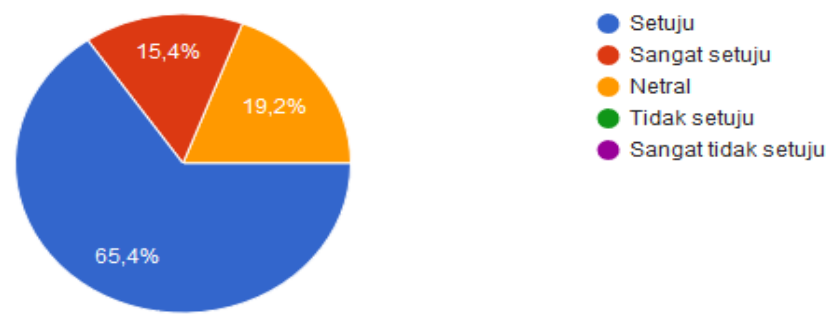

Figure 9. Learning Participation

Figure 9 illustrates that $65.4 \%$ of students "agree," $15.4 \%$ of students "strongly agree," and $19.2 \%$ of students choose a "neutral" scale. Thus, the researchers conclude that the agree scale is the highest percentage. Students always follow orders from the teacher and participate well in learning English through blended learning. Besides, in general, students agree on blended learning, which is applied in the English learning process both offline (face to face) and online (via the WhatsApp application). The three statement items in the table illustrate that students also show their behavior well in terms of participation, attendance, and task collection.

The similar responses are also provided in the excerpt of the interview result as follows:

"I am familiar with this blended learning style, after the Covid-19 pandemic. My response to the use of blended learning in learning English both offline (face to face)

Copyright (c) 2022 Alma Sri Andriyani, Maulina Maulina, Syarif Amin, Rahmat Nasrullah, Asdar 
and online (via the WhatsApp application/group) is good. However, the explanation of the material offline (face to face) is clearer than the explanation of the material delivered online (via the WhatsApp application/group). However, even though the explanation of the material was not clear, I still actively participated in the learning process such as doing assignments, participating in class discussions and others." (NMJ).

It concludes that students are interested and become more active in the learning process that uses a blended learning approach. Therefore, blended learning helps students become involved, and the teaching and learning process will also become more effective.

\section{Emotional Aspect}

In the emotional aspect, students as participants felt happy and satisfied with the English learning process through the blended learning style which was carried out offline (face to face) and online (via the WhatsApp application/group). The following are 3 emotional aspects that are used to analyze students' perceptions in learning English through blended learning.

10. Saya sangat antusias dalam belajar Bahasa inggris yang menggunakan blended learning, yang dilakukan seminggu sekali baik secara tatap muka didalam kelas maupun melalui grup WhatsApp.

26 jawaban
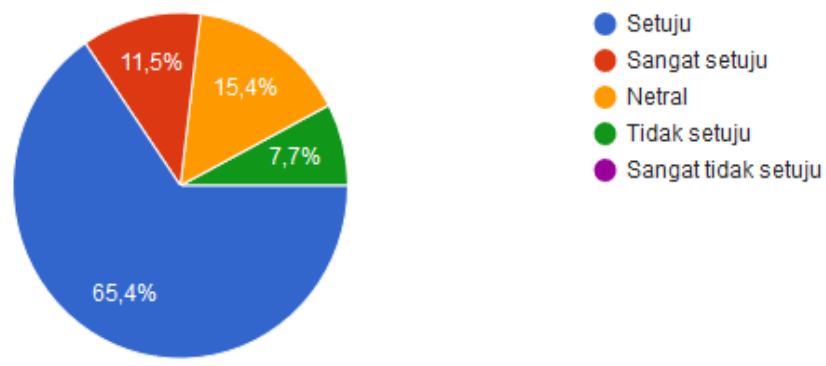

\section{Figure 10. Enthusiasm in Blended Learning}

Figure 10 shows that $65.4 \%$ of students said they "agreed", $11.5 \%$ of students said "strongly agree", $15.4 \%$ of students said "neutral", and $7.7 \%$ of students said they "disagreed". From the results above, the researchers can conclude that there are many choices for the percentage of students' answers. There is a percentage agree, strongly agree, neutral, and also a percentage disagree. However, among these percentages, the percentage agree is the highest percentage. Students agree and are very enthusiastic in learning English through blended learning which is conducted once a week. 
11. Saya merasa senang saat belajar Bahasa inggris menggunakan blended learning baik secara tatap muka didalam kelas maupun melalui grup WhatsApp.

26 jawaban

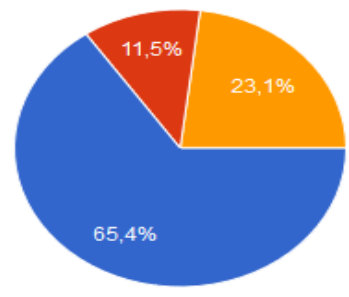

Setuju

Sangat setuju

Netral

Tidak setuju

Sangat tidak setuju

Figure 11. Comfortable in Blended Learning

The items above are answers from participants regarding to Figure 11 comfortable in blended learning. The results of the participants' answers showed that $65.4 \%$ of students "agreed", $11.5 \%$ of students "strongly agreed", and $23.1 \%$ of students chose a "neutral" scale. Based on these results, the researchers can conclude that the majority of students choose the percentage agree. Students are comfortable and enjoy learning English through blended learning.

\section{Learning Satisfaction}

12. Saya pikir belajar Bahasa inggris melalui blended learning, tidak pernah membuat saya merasa bosan, baik itu dilakukan secara tatap muka didalam kelas maupun melalui grup WhatsApp.

26 jawaban
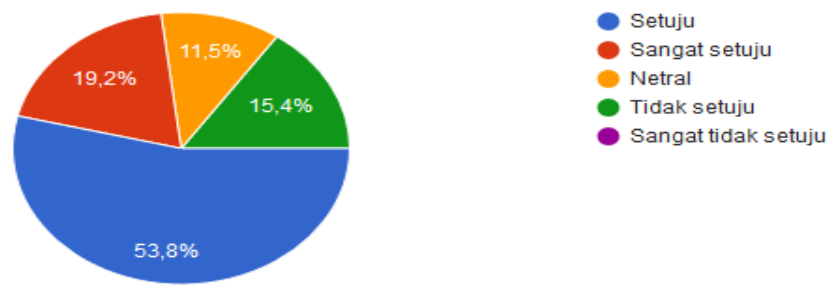

Figure 12. Learning Satisfaction

Figure 12 satisfied in learning which describes the results of students' answers that $53.8 \%$ of students chose "agree", $19.2 \%$ of students chose "strongly agree", $11.5 \%$ of students chose "neutral", and $15.4 \%$ of students chose "disagree". From the results of the answers above, the researchers can conclude that there are many percentages of student answers. However, the percentage of agree scale is the most choice of answers from students. Therefore, students agree and are satisfied and never feel bored when learning English through blended learning. 

follows:

The supporting findings are also provided in the following excerpts as

"I am familiar with blended learning after the Covid-19 outbreak. I also agree when participating in blended learning in learning English both offline (face to face) and online (via the WhatsApp application/group). When learning English by face to face in class I feel happy because the learning is very clear and easy to understand. Then when I study through the Whats App application/group, I feel bored because I don't understand the explanation of the material from the teacher. But apart from that, I feel more focused when studying through the WhatsApp application/group." (BS).

Besides, the following statements are also stated:

"I have known blended learning since after the Covid-19 pandemic. My response when learning to use blended learning in learning English both offline (face to face) and online (via the WhatsApp application/group), I think is good. I also feel happy with this blended learning style. Then, I also enjoy learning English offline (face to face) in class because I understand more about the explanation of the material presented by the teacher. Likewise, when learning English online (via the WhatsApp application/group). I enjoy learning more, more relaxed, and I can also do new assignments given by the teacher." (SNF).

Students gave positive opinions about their emotional feelings towards the learning process using the blended learning approach, especially in learning English. The three statements in the table, it can be explained that more participants agree with the use of the blended learning approach in the learning process. Students as participants feel happy, enthusiastic and not bored during the teaching and learning process, even though this learning activity is carried out once a week. Ali and Sofa (2018), said that the advantages of blended learning were considered to be able to improve students' skills.

\section{Cognitive Aspect}

On the cognitive aspect, students as participants show a good perception so that motivation appears on themselves when participating in the process of teaching and learning activities. The following are 3 cognitive aspects that are used to analyze students' perceptions in learning English through blended learning. 


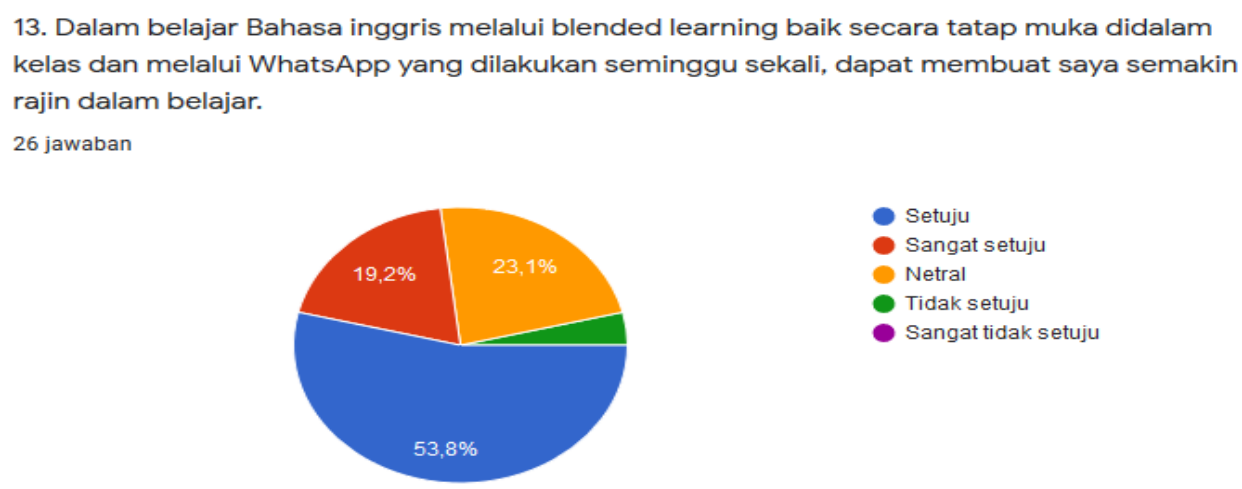

Figure 13. Studious in Learning

The following are the answers from participants regarding Figure 13 studious in learning. The results of the participants' answers showed that $53.8 \%$ of students chose to "agree," $19.2 \%$ of students chose "strongly agree," and $23.1 \%$ of students chose a "neutral" scale. Based on the answers from participants, researchers can conclude that students agree with learning English through blended learning. Students are also more diligent in studying. The "agree" scale is the highest percentage of participants' answers.

14. Saya pikir belajar Bahasa inggris melalui WhatsApp yang dilakukan seminggu sekali, dapat membuat saya menjadi lebih giat dalam belajar.

26 jawaban

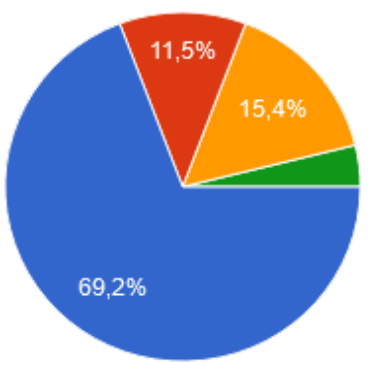

Setuju

Sangat setuju

Netral

- Tidak setuju

Sangat tidak setuju

Figure 14. Favorable

The following are participants' answers regarding Figure 14 about the positive attitude. The answers from participants showed that $69.2 \%$ of students chose to "agree", $11.5 \%$ of students chose "strongly agree", $15.4 \%$ of students chose a "neutral" scale. From the results of the participant's answers, the researchers can conclude that the majority of students agree with learning through WhatsApp groups which is carried out once a week and make themselves favorable in learning. 
15. Saya pikir dalam belajar Bahasa inggris secara tatap muka yang dilakukan seminggu sekali, membuat saya belajar dengan penuh semangat.

26 jawaban

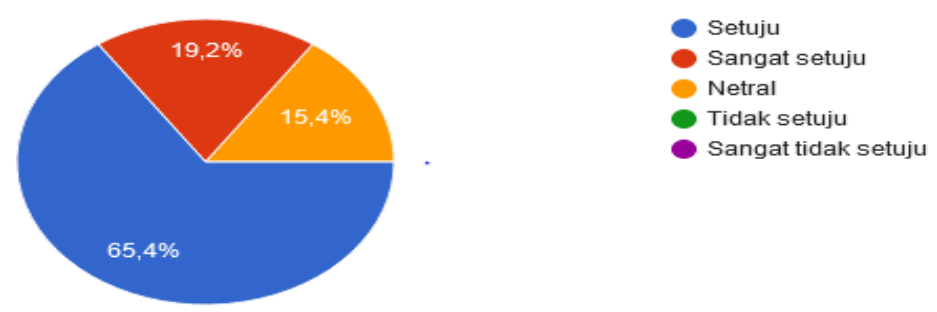

\section{Figure 15. Skillful in Blended Learning}

The following is the result of the answer from Figure 15 about learning enjoyment. The results of the pie showed that $65.4 \%$ of students said they "agreed", $19.2 \%$ of students said "strongly agree", and $15.4 \%$ of students said "neutral".Based on the results of participants' responses, researchers can conclude that students agree and are more favorable when participating in the English learning process through blended learning which is carried out once a week. From the participants' response above, it shows that the majority of students choose the percentage agree.

Participants who described their opinions regarding the three statements on the cognitive aspects of the English learning process both offline (face to face) and also online (via the WhatsApp application). They show their positive perception so that they can motivate themselves when participating in the teaching and learning process using this blended learning model, both offline (face to face) and online (via the WhatsApp application). This is also in line with Ali and Sofa (2018), that this blended learning style can motivate students so that each student can be responsible for their learning process.

The results of the analysis from this interview describe students' perceptions of learning through blended learning both offline (face to face), and also online (via the WhatsApp application/group) which is held once a week. Here the excerpts from the interview results.

"I became acquainted with this blended learning style after the Covid-19 outbreak. My response when learning English using a blended learning approach that is offline (face to face), I think is good and makes it easier for me to understand the explanation of the material from the teacher. But online (via the WhatsApp application/group), I think it's not good and I don't understand the explanation of the material given by the teacher." (DSRM).

Besides, the following statements are also stated:

"I learned about this blended learning after the Covid-19 pandemic.My response when learning English using blended learning both offline (face to face) and online (via the WhatsApp application/group), I don't agree and feel different when studying offline and also online. When learning English offline (face to face) I feel that I understand more about the explanation of the material presented by the 
teacher.And when learning through the WhatsApp application/group, I felt that I did not understand the explanation of the material given by the teacher, and the material explained was incomplete because it was only the main points." (FFS).

\section{DISCUSSION}

On the behavioral aspect, students show good behavior, are polite, always participate, continue to do assignments even though they are sometimes late when collected, and are also present when participating in the learning process. In the offline (face-to-face) learning process, students were participated and remained active during the learning process. As well as in online learning (via the WhatsApp application), students always follow the learning process well and do the assignments given by the teacher. Anderson et al. (2017) that emotional involvement is a positive action overall for a class, including enjoyment and a sense of belonging. From the emotional aspect, students as participants felt happy and always enthusiastic when participating in the offline (face to face) and online learning process (via the WhatsApp application) and did not feel bored while following in the teaching and learning process. From the cognitive aspect, students showed a good perception and were also active and passionate when participating in the learning process using the blended learning model. In addition, students also gain new experiences in learning. Because in addition to learning offline (face to face), they can also learn online (via the WhatsApp application). Activities in the online learning process (via the WhatsApp application) are very easy to understand by students. Besides, cognitive involvement refers to the knowledge that students have in themselves in learning activities, including self-regulation and motivation to study (Pietarinen et al., 2014; Maulina et al., 2019; Maulina et al., 2020; Maulina et al., 2021, Rasyiid et al., 2021; Saputra et al., 2021; \& Lar et al., 2022).

Summing up the data resulting from classroom observation either through face-to-face teaching and learning or through the classroom run in utilizing social media of WhatsApp, questionnaires, interviews, researchers conclude that this blended learning approach provides many benefits for students. Besides managing their time in learning, their enthusiasm is also getting higher. This finding supports the previous relevant studies stating that online learning can also be done anywhere and anytime (Maulina et al. 2019; Maulina et al., 2020; Maulina et al. 2021), and they can manage their time while studying. Therefore, this blended learning approach, both offline (face to face) and online (via the WhatsApp application) learning, gets positive and negative perceptions from participants.

\section{CONCLUSION}

The primary conclusion of the study, beyond the limitation remaining, was that blended learning was successful and well implemented, engaging students' behavior, cognitive, and affective roles in having the principles and features of blended learning of face-to-face and learning utilizing the WhatsApp application to some extent. Learning English through a blended 
learning approach attracts students' attention and agrees with the learning process. Besides, more positive perceptions were revealed when learning English through blended learning. Students showed positive behavior like attending the blended learning classroom regularly and enthusiastically. Besides, students felt comfortable and enjoyed learning English through blended learning. Further, students showed their skillful and favorable learning through blended learning.

In line with the result summary stated, some proposed recommendation generates for students, school teachers, and further researchers. Based on the findings, blended learning helps students learn effectively and efficiently and participate in the learning actively seen from their multi-tasking participation and collaboration in the discussion forum in the classroom and the WhatsApp application through the group settings that raised their learning curiosity. However, varieties of classroom activities are needed to activate more students' engagement in learning through blended learning since it is essential in constructing active interaction and collaboration to help students create reasoning and internalize their ideas in learning English. Besides, school teachers should be encouraged to apply blended learning to gain significant teaching benefits in this era. Further, further research might analyze the relationship between different gender learning through blended learning utilizing other kinds of social media platforms or technological tools to support face-to-face learning.

\section{REFERENCES}

Ahmad, S., Zulfikar, T., \& Hardiana, F. (2020). The Use of Social Media WhatsApp Among English Education Students for Solving Thesis Writing Problems. Humanities \& Social Sciences Reviews, 8(3), 447455.

Ali, F., \& Sofa, E. M. (2018, June). Students' Perceptions Of The Implementation Of Blended Learning in A Large English Class. Edulitics Journal, 3(1), 15-28.

Anderson, S., Hardy, P., Murphy, P., Pilotti, M., \& Vincent, P. (2017). Factors Related to Cognitive, Emotional, and Behavioral Engagement in the Online Asynchronous Classroom. International Journal of Teaching and Learning in Higher Education, 29(1), 145-153. Retrieved from http://www.isetl.org/ijtlhe

Andretti, A. L. (2016). Exploring Student's Blended Learning through Social Media. ComTech, 7(4), 245-254.

Azizan, F. Z. (2010). Blended Learning in Higher Education Institution in Malaysia. Proceedings of Regional Conference on Knowledge Integration in ICT, 454-466.

Demuth, A. (2013). Perception Theories. Trnava: Edicia Koginitivne Studia.

Graham, C. R. (2013). Emerging Practice and Research in Blended Learning. In G. M. Michael, Handbook of Distance Education (pp. 333-350). 
Kristine C, M. (2017). Emotional and Cognitive Engagement in Higher Education Classrooms. ProQuest Dissertations Publishing, 1-8. doi:10688303

Lar, M. A. M., \& Maulina, M. (2021). Students' Self-Confidence in Speaking for a Live Presentation: A Literature Review. Klasikal: Journal of Education, Language Teaching and Science, 3(3), 88-95.

Martin, F., \& Ertzberger, J. (2013). Here and Now Mobile Learning: A Experimental Study on the Use of Mobile Technology. Computers and Education, 68, 76-85.

Maulina, M. (2015). The Correlation among Gender, Language Learning Strategies, and English Achievement of English Department Students Tarbiyah Faculty. Ethical Lingua: Journal of Language Teaching and Literature, 2(1), 27-41.

Maulina, M. (2019). Gender Differences in Language Development, Acquisition, Comprehension, and Production. Proceedings of the 65th TEFLIN International Conference, 65(01).

Maulina \& Rusli, T. I. (2019). Pre-Service Teacher in Implementing Teaching Methods at TEFL Class. KLASIKAL: Journal of Education, Language Teaching and Science, 1(1), 19-26.

Maulina, Geelan, D., Basri, M., \& Noni, N. (2021, February). Constructing WhatsApp Based-Speaking Instructional Material (WABSIM) for EFL Teaching and Learning: A Need Analysis . Asean EFL Journal, 28(1.2), 89-110.

Maulina, Noni, N., \& Basri, M. (2019). WhatsApp Audio and Video ChatBased in Stimulating Students' Self-Confidence and Motivation to Speak English. Asian EFL Journal, 23(6.3), 181-203.

Maulina, Noni, N., \& Basri, M. (2020). Basic Speaking: WhatsApp-Based Daily Conversation. Yogyakarta: Deepublish

Mismara, J. (2019). Students' Perception on Using Social Media For Learning English. UIN Ar-Raniry Banda Aceh, 1-43.

Montag, C., Blaszkiewicz, K., Sariyska, R., Lachmann, B., Andone, I., Trendafilov, B., et al. (2015). Smartphone Usage in the 21 st Century: Who is Active on WhatsApp. BioMed Central Res Notes, 8(331), 1-6.

Morse, J. M., \& Linda, N. (2016). Mixed Methos Design: Principles and Procedures. London and New York: Routledge.

Pietarinen, J., Pyhalto, K., \& Soini, T. (2014). Students' Emotional and Cognitive Engagement as the Determinants of Well-Being and Achievement in School. International Journal of Educational Research, 67, 40-51. doi:https://doi.org/10.1016/j.ijer.2014.05.001

Qamar, K., Riyadi, S., \& Wulandari, T. C. (2019, August). Utilization of Whatsapp Application as Discussion Media in Blended Learning. Journal of Education and Learning (EduLearn), 13(3), 370-378.

Qiong, O. (2017). A Brief Introduction to Perception. Studies in Literature and Language, 15(4), 18-28.

Rasyiid, R. N., Maulina, M., Resueňo, C. P., Nasrullah, R., \& Rusli, T. I. (2021). Instagram Usage in Learning English: A Literature Review. 
Tell: Teaching of English Language and Literature Journal, 9(2), 133-146. DOI: http://dx.doi.org/10.30651/tell.v9i2

Sakina, R., Kulsum, E. M., \& Uyun, A. S. (2020). Integrating Technologies in The New Era Normal: A Study of Blended Learning. International Journal of Quantitative Research and Modeling, 1(4), 181-193.

Saputra, U. R., Maulina, M., Nasrullah, R., \& Sakkir, G. (2021). Students' Sentence Errors on WhatsApp Daily Status: A Literature Review. Celebes Journal of Language Studies, 1(1), 23-31.

Sayan, H. (2016). Affecting Higher Student Learning Activity by Using Whatsapp. Europian Journal of Research and Reflection in Educational Sciences, 4(3), 88-93.

Trowler , V. (2010, November). Student Engagement Literature Review. 11, $1-15$

Putra, M. T. I., Maulina, M., Muthmainah, M., Asrifan, A., Apriani, E., Resueňo, \& Peroddin. (2021). Teaching Communicative Grammar: A Literature Review. CAPE COMORIN: An International Multidisciplinary Double-Blind Peer-reviewed Research Journal, 3(02), 63-68.

Zainal, A. S., Said, A., \& Maulina, M. (2022). Analisis Pemberdayaan Pendidikan di Kota Kendari dengan Metode One Help One. Jurnal Ilmu Manajemen Sosial Humaniora (JIMSH), 4(1), 1-11. 